最適処方に導くアカデミック・ディテーリング〜基礎薬学とエビデンス活用による処方支援〜

小茂田昌代, $*, a, b$ 山本美智子 $c, \uparrow$

\title{
Academic Detailing Leading to Optimal Prescription: Supporting Prescription with Basic Pharmaceutical Sciences and Evidence
}

\author{
Masayo Komoda ${ }^{*, a, b}$ and Michiko Yamamoto ${ }^{c, \uparrow}$ \\ ${ }^{a}$ Faculty of Pharmaceutical Sciences, Tokyo University of Science; 2641 Yamazaki, Noda, Chiba 278-8510, Japan: \\ ${ }^{b}$ Division of Academic Detailing Database, Research Institute for Science and Technology, Tokyo University of \\ Science; 2641 Yamazaki, Noda, Chiba, 278-8510, Japan: and 'Department of Drug Informatics, Center for \\ Education \& Research on Clinical Pharmacy, Showa Pharmaceutical University; \\ 3-3165 Higashi-Tamagawagakuen, Machida, Tokyo 194-8543, Japan.
}

社会情勢の変化や高齢化社会の到来，そして複雑 化する医療ニーズに応えるため，日本の薬剤師の役 割は広がってきている，薬剤師は，薬物療法にその 専門性を発揮し，国民の健康への貢献が期待される ところである。そのためには，質の高い薬剤師の養 成も，日本の医療システムを継続し，向上させるた めには不可欠である.このような状況の中，薬剤師 の活動として，注目されているのがアカデミック・ ディテーリングである，これは，医療従事者，特に 医師に対する教育的なアウトリーチの手法である. 訓練を受けたアカデミック・ディテーラーが，医薬 品や薬物治療に関し, 有効性・安全性・費用対効果 を考慮した適切な臨床上の判断が行えるように支 援・推進する活動をいう。

薬剂師がアカデミック・ディテーリング活動によ り，医薬品情報の評価や教育的資質を見極める医薬 品情報リテラシーを身に付け，相手のニーズを考え た情報提供を行うコミュニケーションスキルを向上 させれば，薬物治療の最適化に向けた更なる社会的 貢献が期待できる。海外では既にアカデミック・

\footnotetext{
$a$ 東京理科大学薬学部（干278-8510 千葉県野田市山崎 2641), $b$ 東京理科大学研究推進機構総合研究院アカデ ミック・ディテーリング・データベース部門（テ2788510 千葉県野田市山崎 2641), c昭和薬科大学臨床薬学 教育研究センター医薬品情報部門（干194-8543 東京都 町田市東玉川学園 3-3165)

現所属: †熊本大学大学院生命科学研究部 (薬学系)

(干862-0973 熊本市中央区大江本町 5 番 1 号)

*e-mail: komo1207@rs.noda.tus.ac.jp

日本薬学会第 138 年会シンポジウム S51 序文
}

ディテーリングが薬学教育に導入されており, 国内 でもその導入を視野に入れ，薬片師の専門性を確立 する教育体制作りに寄与したいと考える。 そこで, 日本におけるアカデミック・ディテーリングは, 「基礎を臨床につなぐ科学的視点を強化し，さらに エビデンスを基にした公正中立な医薬品比較情報を 能動的に発信する新たな医薬品情報提供アプロー チ」として定義した．医薬品の科学的な特性と根拠 に基づいた情報の提供により最適な薬物治療，特に 医療費抑制をも目的としており，医療行政にも大き な影響を与えるものとなると考える。

同じ効果を示す医薬品の科学的特性から比較し, 使い分けポイントを示すアカデミック・ディテーリ ングは，患者にとって最適な医薬品が処方されるこ とが期待され，その結果，安易な新薬の処方集中を 回避し，医療費抑制も期待されると考える。アカデ ミック・ディテーリングの実践には，医療の現場と 大学教員, そして製薬企業との更なる連携が必要と なり，薬学教育の充実にも大きく貢献することが期 待される. 本シンポジウムでは，アカデミック・ ディテーリングの普及に向けた大学，医療現場，製 薬企業の様々な取り組みを紹介し, アカデミック・ ディテーリングの将来像に迫る. 